\title{
THE HUMAN BODY BECOMING THE TERRORIST'S WEAPON: THE PHENOMENON OF SUICIDE TERRORISM
}

\author{
Fahri ERENEL*, Nuriye NİĞDELİOĞLU HAPPANI***
}

\begin{abstract}
Suicide terrorism, which has been prominent for generations by pro-violent non-state actors, is used by terrorist groups, guerrilla groups and insurgents. Particularly in the post-Cold War period, the human body has become the main object of terrorist activity. The suicide bomber has been used in a variety of ways throughout history, the preferred choices varied according to the aims of the attackers. Suicide bombers can walk to their destination using a suicide belt, explode their own bodies using different vehicles or public transport. Especially in the occupied territories of the Middle East, the possibility of reaching a paradise that offers a better life by humiliating both their religion and themselves is the last task that gives hope for many suicide bombers. According to research by Adam Fosson, the request of a Palestinian child who wants to become a martyr is almost the same as an American child who wants to visit Disneyland.
\end{abstract}

Keywords: Suicide Terrorism, Motivation, Recruiting and Assigning Suicide Terrorist, Demographic Characteristics

\section{INSAN VÜCUDUNUN TERÖRISTIN SILAHINA DÖNÜŞMESİ: INTIHAR TERÖRIZMI FENOMENI}

\author{
$\ddot{O} z$
}

Şiddet yanlısı devlet dışı aktörler tarafindan nesiller boyunca öne çıkan intihar terörizmi, terörist gruplar, gerilla grupları ve isyancılar tarafindan kullanılmaktadır. Özellikle Soğuk Savaş sonrası dönemde insan bedeni terör faaliyetinin temel objesi haline gelmiştir. İntihar bombactsı tarih boyunca çeşitli şekillerde kullanılmış olup tercih edilen seçimler saldırganların amaçlarına göre değişiklik göstermişstir. Teröristler intihar kemeri bağlayarak gidecekleri yere yürüyebilirler, farklı araçlar ya da toplu taşıma araçları kullanarak kendilerini patlatabilirler. Özellikle Ortadoğu'da işgal altındaki topraklarda hem dinlerinin hem de kendilerinin aşağılanmasından dolayı daha iyi bir yaşam sunan cennete kavuşma ihtimali, intihar bombacısı olmak isteyen birçok kişi için umut veren bir son görevdir. Adam Fosson'un araştırmasına göre Filistin'de şehit olmak isteyen bir çocuğun isteği ile Disneyland'ı ziyaret etmek isteyen Amerikalı bir çocuğun isteği neredeyse aynıdır.

Anahtar Kelimeler: İntihar Terörizmi, Motivasyonu, İtihar Bombacısının Temini ve Yetiştirilmesi, Demografik Yapısı

\footnotetext{
* Doç. Dr., İstinye Üniversitesi, Sosyal Bilimler Enstitüsü ferenel@istinye.edu.tr, ORCID: 00000001-8943-7265

** Doktora Öğrencisi, Milli Savunma Üniversitesi, Atatürk Stratejik Araştırmalar Enstitüsü, nuriyenigdelioglu@gmail.com, ORCID: 0000-0001-9372-6596
} 


\section{INTRODUCTION}

Although it has existed for centuries, a universal definition of terrorism has not been established, so a global definition of suicide terrorism, which is a subcategory of terrorism, has not been made (Marthoz, 2017: 19). Considering the common definitions in the literature, suicide terrorism can be defined as the act of violence that a person will commit based on political, nationalist or religious reasons, with the awareness that he or she will die. The number of suicide attacks used as an act of killing and revenge, which are among the most significant political activities of today, is increasing day by day. Terrorists always argue that their cause is justified and adopt the rule of sacrificing themselves by shaping their lives accordingly. According to some researchers, the death of the suicide bomber is essential and inevitable for the action to be successful (Ward, 2018: 90).

Suicide bombers, one of the most important tactics of terrorism, have been used in more than forty countries in the last thirty years and caused the death of approximately fifty thousand people. The reason why terrorist organizations and guerrilla groups frequently use the method of suicide attack is their desire to obtain the highest number of victims at the most affordable cost. The average number of people who can be harmed by using the armed attack method in terrorist incidents is 3.32, 6.92 in attacks targeted with remote-controlled explosives, 81.48 in terrorist incidents with suicide vests, 97.81 people who are victims when a car with explosives is used (Pedahzur, 2006: 2).

\section{A BRIEF HISTORY OF SUICIDE TERRORISM}

Although their origins date back to ancient times, suicide attacks started to increase between 1980 and 1990, especially after the Cold War. From past to present suicide terrorism has a long history with terrorist organizations such as Zelots, Japanese Kamikazes, Tamil Tigers, Al Qaeda and ISIS. Historically, the first suicide attack known as the Hebrew Bible caused the deaths of around 3,000 Palestinians, knowing that Samson would die along with his victims, which was called an act of revenge. The second manifestation of suicide terrorism, "Zelots" living in Palestine, in the Old Testament, "Jewish Sicari", also known as daggermen, caused the deaths of Jews and many statesmen who collaborated with the Romans in crowded places (Canter, 2010: 20). After the French revolution, which was the beginning of modern terrorism, Robespierre introduced "statesponsored terrorism" to the academic literature by using terrorist activity for state purposes (Burgess, 2003: 3). 
Terrorism started to come to the fore in the international arena with the assassination of Austria-Hungary Archduke Franz Ferdinand by Serbian nationalist Gavrilo Princip, who ignited World War I(Berge, 2014). During the Second World War, Kamikaze pilots sacrificed themselves by carrying out crash-dive bombing missions on enemy targets "in the name of the emperor" on American bases and warships (Madsen, 2004: 1). At the beginning of the Cold War, the kidnappings and assassinations described by David Rapoport in the "New Left Wave" theory began to take place in NATO countries, Soviet leaders assisted terrorists through their intelligence and terrorism reached its peak (Kaplan, 2016: 6). In the assassinations organized by the Tamil Tigers, Indian Prime Minister Rajiy Gandhi and Sri Lanka President Prendesa lost their lives and began the modern suicide bombing era (Schweitzer, 2000). In the beginning, suicide bombers, which were active at the regional level, the emergence of terrorist organizations such as ISIS, Al-Qaeda and especially after the attacks of September 11, 2001, suicide terrorism gained an international dimension and states started to take joint actions to combat this problem (Smith \& Zeigler, 2017: 1).

\section{A CONCEPTUAL FRAMEWORK FOR SUICIDE TERRORISM}

As a matter of fact, suicide bomber has begun to be defined by states or international organizations with concepts such as "terrorist, freedom fighter, noble fighters, lone wolf or jihadist" according to the terrorist organization to which the perpetrator is affiliated. It has begun to be classified using the concepts of "freedom fighter" for suicide actions carried out to save nations from their captivity, "terrorist" for suicide bombers who are Muslims, "lone wolf" for suicide bombers carried out by white men (Corbin, 2017: 455).

Schweitzer described the suicide bomber as the act of attack in which a person consciously motivated by violence, belief, or political reasons blows himself up with a chosen target (Moghadam, 2006: 712). Robert Pape studied 315 suicide bombers in 1980-2003, highlighting the concept of "suicide terrorism" and expressed it as the best method of weak organizations that have no other way to achieve political goals against democratic governments (Pape, 2005: 14). Mohammed M. Hafez, who examined the problem of how suicide attacks occurred in Iraq, defined suicide terrorism as the collapse of the system, sectarian war and "suicide attack" carried out to produce a failed state (Hafez, 2006: 592). Ami Pedahzur used the concept of "suicide terrorism" to describe it as an act of violence with zero probability of survival . Harvard University Professor Alberto Abadie emphasized that there is a negative correlation between suicide terrorism and 
poverty and argued that the real motivation of the suicide bomber is religious, ideological, political and hatred feelings(Abadie, 2004: 51). Riaz Hassan portrayed the suicide bomber as self-destruct against the enemy for a political cause. Defending that there is not a single type of suicide bomber (Riaz, 2011: 18), Christoph Reuter has highlighted the Tamil Tigers and PKK terrorist organizations by stating that the suicide attacks are not only based on religion but may also be of sectarian origin. However, Reuter points to the Iranian suicide bombers whose origins date back to the Karbala incident in the 7th century and emerged again with the Iran-Iraq war (1980-1988), The Palestine Liberation Organization that emerged after the Israeli-Palestinian conflicts, and most importantly, how the Japanese Kamikazes' culture of self-sacrifice, the Bushidos(samurai culture), was replaced by Allahu Akbar (Reuter, 2004: 130).

There is a direct correlation between the death of the suicide bomber for the success of the mission. Loyalty and honor, the courage of a suicide bomber, his commitment to beliefs, the thought of becoming a hero by sacrificing his own body have always been considered a strong motivation for suicide bombers. Although the main goal of a suicide attack is to physically destroy the place where it will take action, its main goal is to create a psychological war that can affect states and society. The suicide bomber uses the scene of the action as a political theater stage (Bryant, 2003: 241). Lankford evaluated four different types of suicide terrorist. (conventional, coerced, escapist and indirect). "Conventional" suicides are those who want to commit suicide for the same reason as many suicidal people in the community (e.g. social isolation, depression, and despair). "Coerced" suicides, Kamikaze Pilots alike will be accused of cowardice if they are forced to take the action and fail. "Escapist", Nazi generals who refuse to surrender to the enemy and committed suicide or in other words, after 9/11, instructing the bodyguards of Osama Bin Laden to shoot him, if the American soldiers are caught. Those who can easily hide themselves in the "indirect" society, Mohammed Atta, the leader of the 9/11 attacks, graduated from the architecture department in Germany, and the far-right Norwegian Anders Behring used farming to produce bombs(Lankford, 2014: 357).

\section{PROFILE OF A SUICIDE BOMBER AND THE CHANGING PROFILE OF THE TERRORIST}

Is it possible to profile the terrorist or is there any way to describe who may be a terrorist? Many questions that are difficult to answer actually explain why political scientists and state authorities are particularly concerned with psychological factors 
in the fight against terrorism. If the tactics and methods used by terrorist organizations to recruit new members of the organization can be determined in advance, it will be easier to prevent the emergence of terrorist groups. All research on terrorism, terrorist or suicide bomber has still not been sufficient to derive a single definition of terrorist (Rae, 2012: 64).

Frederick Hacker divides the perpetrators of terrorism into three categories: individuals with: the crusaders, the criminals, and the crazies. In order to understand a terrorist, it is not enough to evaluate them for humanitarian reasons, it is also vital to examine the characteristics of terrorists while planning or carrying out terrorist acts. Frederick Hacker defined people with psychotic disorders as people with emotional disorders who live for reasons that do not make sense to anyone else. Persons or criminals with high criminal potential prefer to be terrorists for personal gain (Haberfeld \& Hassell, 2009: 37).

Individuals with a struggling and rebellious spirit generally commit terrorist acts in order to gain power and prestige, on the grounds that they serve a great cause in an understanding of anarchism and idealism. The identity of the terrorist behind the Kalashnikov or the bomber wearing a suicide vest is very important for the control of law enforcement and state officials. For example, sending the bomb from one country to another at the airport is an action that a criminal can take more easily, as he/she is experienced in illegal activities. Insurgents and warriors are more willing to blow themselves up with their victims, because at the end of their action there is often a promise of reward in future life. For these reasons, Hacker stated that the aims and objectives that caused the terrorist to perform the action were different. In the early years of the twenty-first century, most of the people and groups involved in terrorist acts had a warrior or combative or rebel spirit. Combatants who are most involved in modern terrorism are professional people who are well trained, well prepared, and have the discipline to blindly obey a cause (Combs, 2002: 131).

The most common method used in creating a terrorist profile is demographic structure analysis based on racial or ethnic origin. Racial profiling has been used by many countries, mainly the USA, to identify potential terrorists, especially after the 9/11 attacks. Another method frequently used to profile terrorists is to evaluate the terrorist profile based on gender. When the terrorist organizations in the world are examined, although the number of male terrorists is high, female terrorists are more advantageous against law enforcement agencies. Women are less suspicious of law enforcement than male terrorists, and the female body has a higher capacity to hide 
explosives than male terrorists. According to Karla J Cunningham, motivations of female suicide bombers and male suicide bombers are different (Jacques \& Taylor, 2008: 305).

It is assumed that female terrorists are committed to a cause and ready to use violence to achieve their goals. However, women are stuck in society and prefer to be terrorists or suicide bombers as a way of emancipation due to their gender inequality and their exposure to violence. It has been stated that women's motivation is often represented by a feminist movement or the result of gender pressure. Barbara Victor's book "Army of Roses" evaluated the gender inequality and empowerment of women affected by the patriarchal social structure as an important factor in the participation of women terrorists of the Palestine Liberation Organization (Victor, 2003: 7). However, the social and religious norms of the society where terrorist organizations exist and the motivation of women terrorists come to the fore. For example, the Palestine Liberation Organization promises female suicide bombers to commit suicide attacks in order to show their loyalty and devotion to their wives and as a reward that they will reunite with their wives in paradise in their future lives. According to Robert Pape and Ariel Merari, (Merari, 2010: 139) most Palestinian suicide bombers are single males between the ages of 17-24. Of the 381 suicide perpetrators examined by Robert Pape between 1980 and 2003, 15\% were women. Ariel Merari found that $86.8 \%$ of 2284 suicide attacks in the world between 1974 and 2008 were carried out by single male suicide bombers. According to the same research by Ariel Merari, 3\% of suicide bombers affiliated with Al Qaeda are women (Merari, Webber, Klein, Kruglanski, \& Brizi, 2017: 7).

According to the data of 2020,56\% of the YPG / PKK terrorist organization, which has the highest rate of women among terrorist organizations, consists of women (Demircan \& Aksüt, 2019). While 96\% of terrorist organizations that carry out their activities with an Islamic or jihad ideology are male terrorists, $79 \%$ of organizations that have an orientation towards an ethnic separatist ideology are men. 


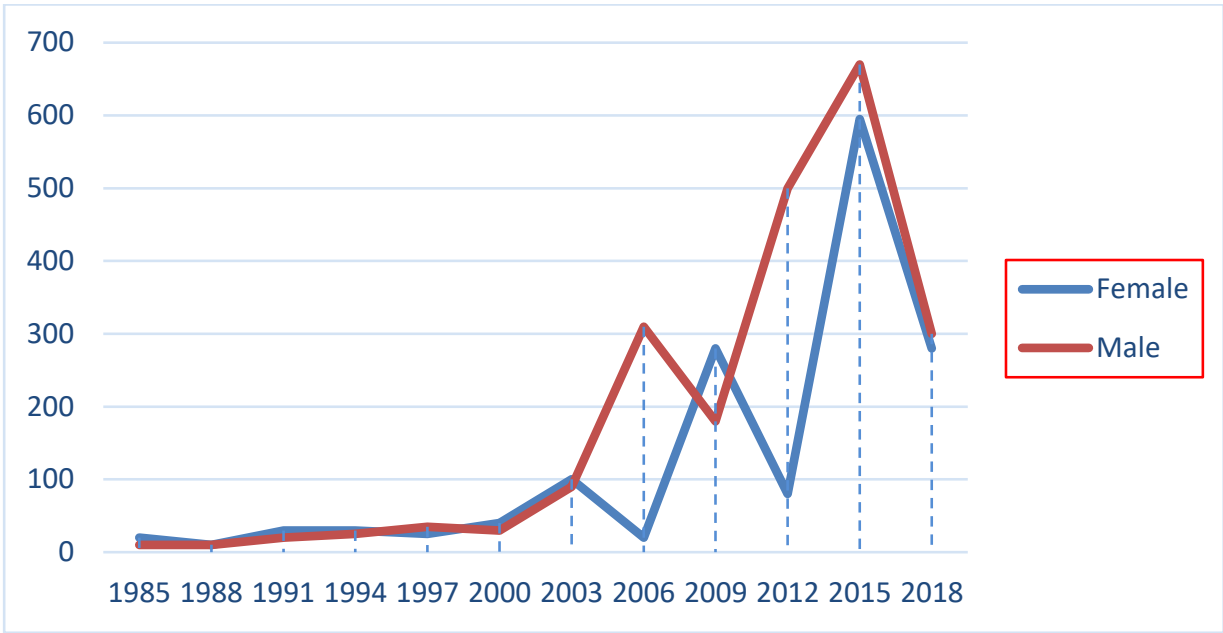

Figure-1. Suicide Attacks, Men and Women, 1985-2018 (Source, Global Terrorism Index Report 2019 (GTI).

According to researchers Robert Pape (Pape, 2005: 142), Mia Bloom (Bloom, 2005: 109), Jessica Stern (Stern, 2003: 52), Shaul Shay (Shay, 2017: 83), and James Q. Wilson (Krueger, 2007: 2), who are interested in suicide terrorism, many suicide bombers have a good educational background, many of them agree to being high school or university graduates. In addition, the socio-economic level of many terrorists is middle-income, even high-income, and many of them are religious. Although it is prohibited by the Qur'an, suicide attacks carried out over the concept of martyrdom are not considered by terrorist organizations as suicide acts, but rather as a sacrifice in the way of serving Allah. According to Harvey W. Kushner's study in 1996, most Palestinian suicide bombers have high income and are graduates of Birzeit University in the West Bank (Kushner, 2003: 353).

According to Mali Soibelman, most terrorist organization leaders are welleducated university graduates. Tamil Tigers have equal proportions of female and male terrorists, training camps training terrorists are subjected to the same training regardless of gender. John Francis Rosenberger predicted that the suicide bomber began to use destructive and damaging methods with the idea that the enemy deserves all kinds of evil, emphasizing the motivation of revenge.

Vamık Volkan explained suicide terrorism with metaphorical tent's canvas. People have "two identities" from childhood. The first is the individual's own (individual identity), the second is the broader identity and encompasses many, like a large tent (large group or ethnic identity). Chosen traumas, chosen victories and 
the psychology of victimization are in this tent, while the pole that keeps the tent standing is held by the group leader. Unless this tent is attacked from the outside, group members will not notice it as long as it stands firmly (Volkan, 2013: 221222) Especially with the re-emergence of trams in history, individual identity becomes insignificant and the struggle for large group identity begins. In suicide terrorism, the attacker sacrifices life for the identity of the large group by ignoring the individual identity, although attacker will die. The suicide bomber is now a representative of large-group identity, and main purpose in life is to best complement the demands of large-group identity. The aim of the attacker is not to kill oneself, innocent people or the enemy, but the main important thing is to attract the attention of the large group identity by carrying out the bombing with dignity (Volkan, 2005: 4). He argues suicide bombers have an imbalanced personality and try to internalize some external factors in order to keep their inner world in balance. He also stated that suicide bombers experienced degrading events in their childhood or adolescence and they tend to show more violence because they grew up in environments where domestic violence was used. He emphasized that in training camps that train suicide bombers, leaders of the organization are experienced in identifying people who fit this profile. Militants seeking new terrorists for the terrorist organization prefer people who are mentally immature, unemployed, antisocial and do not make sense for life itself. In addition, Vamık Volkan, who examined the suicide bombers who carried out the September 11, 2001 attacks, emphasized the possibility that all of them may have experienced psychological trauma despite having families with high education and high income (Lester \& Gunn, 2014: 130).

Jerrold M. Post argues that those who resort to violence and terrorism distinguish between "us" and "them". In fact, at the end of this categorical distinction, which should be seen as a kind of identity-building process through differentiation by comparing itself with "others" begin to be perceived as the source of all evil. "Us", on the other hand, are seen as a virtuous community fighting for freedom and justice. According to this psycho-logic, the "others", who are seen as the source of all problems and evils, must be destroyed. With this understanding, eliminating "others" by resorting to violence can be seen as a way that is both fair and virtuous. In particular, he argues that there is a search for an identity behind the violence against "the other" and an effort to destroy those who are perceived as an enemy by waging war. (Post, 1990: 25-26) 
Joan Lachkar argued that with the death of the father, violence, cruelty and sexual exploitation of children in the conflicts in the Middle East, children who grow up in these societies can identify with a charismatic leader who protects them and is angry and aggressive. Most suicide bombers are shy, quiet and introverted boys who need power and want to be heroes. Comprehensive biographies of individuals with details of birth, childhood and adolescence are needed to create personality typologies of suicide bombers or terrorists. In an interview with a senior leader of Hamas, Jessica Stern stated that terrorists using knives have an anxious personality and can become aggressive in response to an incident, terrorists using guns are more cold-blooded, and those who are suicide bombers or wearing suicide vests need momentary courage (Stern, 2003: 39).

\section{THEORETICAL APPROACH}

Understanding the strategic, social and individual rationale of suicide terrorism is extremely important in combating terrorism. According to Robert Pape, suicide terrorism has three components. Strategic logic, social logic and individual logic. Strategic logic is that if terrorist groups did not believe that they could achieve their political goals through suicide attacks, they would not use it as tactics. Social logic, terrorists would not have continued suicide attacks if they had not received social support from their national community. Individual logic of suicide terrorism, suicide attacks would not be so widely used without volunteers to commit suicide attacks (Pape, 2005: 19).

\subsection{Individual Logic of Suicide Terrorism}

The individual logic of suicide attacks is different from other logical approaches. Pape analyzes the situation of many suicide bombers in Emile Durkheim's "altruistic suicide" framework. Altruistic suicide is the opposite of selfish suicide and argues that excessive loyalty to society leads to suicide. In this type of suicide, it is thought that a social responsibility is fulfilled, in case of failure, they are accused of dishonor and religious punishments can be applied. Altruistic suicide is the sacrifice of one's life for the sake of a value that is superior to one's own life and the thought that he/she will be rewarded for this action. As a result of a mission he/she could not complete, he/she is expected to kill himself/herself to protect honor (Stack, 2004: 10). Durkheim classifies suicides for social reasons in nineteenth-century Europe as egoistic suicides, altruistic suicides and anomic suicides. Egoistic suicides occur when the person feels lonely due to the weakening or breaking of social ties. As a result of loneliness, life becomes meaningless for 
the person and suicide is seen as a way of salvation. Altruistic suicides commit suicide not only when a person is isolated from society and feels lonely, but also when she is deeply connected to society. Anomic suicides occur as a result of the negative effects of changes in the structure of society and dissolved norms as a result of social crises (Graitl, 2017: 116).

Based on the altruistic suicide approach, it has been suggested that high levels of social integration and respect for social values can lead even normal people to suicide attack. Pape argues that the perception that suicide bombers are experienced criminals, are constantly losers in society and that they are problematic people is wrong. He argues that these people do not have any psychological and economic problems, they have very strong social ties, they are a part of the society, they are willing to sacrifice themselves in order to benefit their nations and to end the foreign occupation in their country. They believe that suicide attacks, also called martyrdom operations are necessary due to the imbalance of power between the occupying forces and those living in the occupied territories. In other words, the duty of being a suicide bomber is accepted with the understanding of a soldier ready to sacrifice himself/herself during a war (Pape, 2005: 116). In a similar approach, Vamık Volkan emphasizes that suicide bombers believe they are doing something useful for society by giving up their own lives and that they feel obliged to do so in order to continue what they are defending. He states that the excessive level of political and economic pressure and concerns about the continuation of the group are effective in legitimizing suicide attacks (Volkan, 2010: 1).

\subsection{The Strategic Logic of Suicide Terrorism}

The desire to achieve a specific political goal is the root cause of suicide attacks. In order to meet the demands, the other side is tried to be put under pressure through suicide attacks. According to Pape, the main target of the strategic logic of suicide attacks has a nationalist characteristic, not a religious or Islamic characteristic. He also stated that there are nationalistic motivational factors among Palestinian groups that do not dominate the religious aspect. He indicated that the vast majority of suicide attacks in the last two decades were carried out by secular organizations such as the Tamil Tigers and PKK/YPG. The violence inflicted by the occupying countries due to the resistance they face in the occupied territories is one of the factors that cause the increase in suicide attacks, violence causes more violence (Pape, 2005: 19). 
On the other hand, suicide attacks mostly target democratic states. The main reason is that these attacks are easy to organize in democratic countries and their impact on the public is high. It is known by terrorists that suicide attacks are an effective method. Until suicide terrorism was used as a tactic, terrorist organizations such as the PKK/YPG, the Lebanese Hezbollah, Hamas and AlQaeda used other forms of violence and terror tactics. When they started committing suicide attacks, they saw more impact on the target audience. The withdrawal of Israeli forces from South Lebanon in 1985 and the negotiations of the Sri Lanka government with the Tamil Tigers in 1994 and 2001 are examples of the organizational success of suicide attacks. The success of a terrorist group affects other terrorist groups. The success of the Lebanese Hezbollah in suicide attacks against Israel, France and America resulted in the withdrawal of these countries from Lebanon in the early 1980s, and this process motivated groups such as Tamil Tigers and Al-Qaeda (Parker \& Sitter, 2016: 6).

\subsection{The Social Logic of Suicide Terrorism}

Social support is indispensable for suicide terrorism to be successful. Because social support enables new members to be recruited, prevents the detection of suicide bombers, and paves the way for the phenomenon of martyrdom to be settled and to be believed. In some societies, suicide bombers are seen as heroes who sacrificed themselves to save their country from foreign occupation. In other words, the phenomenon of martyrdom is shaped by the society. High-profile funeral ceremonies for suicide bombers, commemoration ceremonies, video footage of the martyr, writing their names on the walls and sharing pictures are factors that strengthen the perception and phenomenon of martyrdom. Pape argues that the main reason for suicide terrorism is the phenomenon of nationalism rather than factors such as personal alienation, unemployment, social humiliation, and religion (Pape, 2005: 55).

Nationalism, which includes shared ethnic values, common language, historical ties, creates resistance against foreign powers to take control of national territories. These determinations of Pape enabled him to create the "Nationalist Theory of Suicide Terrorism". According to the theory, when a democratic state invades a society, nationalist feelings increase in that society and social support for martyrdom results in suicide terrorism. The religious difference between the occupying state and the local community also causes identity differentiation, which is effective in the exacerbation of suicide terrorism. In other words, suicide terrorism is part of the national liberation strategy. The difference between the 
identity of the occupying state and the local community causes nationalist feelings to rise. Likewise, there is a possibility that social rebellion and suicide terrorism may reinforce the previously weak or absent national identity (Pape, 2005: 57).

\section{RECRUITMENT, SELECTION, AND TRAINING OF SUICIDE ATTACKERS}

Pakistani Shahid (only 14 years old) explained the process of joining the Taliban organization with the following sentences:

If you want to find me after death, you will never find my whole body, you will find me in small pieces, then my body will be reassembled and when the judgment day comes, Allah will call me to take my testimony. The God asks me why did you do it, I will answer that I gave my life to fight the unbelievers for you. Afterwards, Allah will see that my intention is to destroy the evil deeds of Islam and will reward me with paradise (Obaid-Chinoy, 2009).

As can be seen from these sentences, it is not easy for citizens of politically stable, democratic and wealthy countries to accept the fact that there are children who want to be suicide bombers when they grow up, or even before they grow up. Suicide terrorism is a promising important task for future generations in societies where civil war and civil conflict are intense, such as Pakistan, Afghanistan or Iraq. Throughout history, suicide terrorism is not only in Middle Eastern societies, from Spain to England, Indonesia, Russia, Sri Lanka and Turkey is a kind of terror in many countries.

The reason why this method, which requires the terrorist to use his/her own body as a weapon, has become so popular is still questioned by sociologist and psychoanlysts (Riaz, 2011: 16). Suicide terrorism may seem like an unreasonable decision given a person's self-execution. However, many people in different parts of the world continue to volunteer to become suicide bombers, and terrorist organizations radicalize and financially support these attackers by training. Mia

Bloom describes this phenomenon as the worldwide appeal and charming of suicide terrorism (Bloom, 2005: 4).

RAND Corporation has specified the characteristics sought in individuals who will become members of the organization as follows (Gerwehr \& Daly, 2006: 76).

- Feeling emotionally and physically dissatisfied in their lives,

- Raised with cultural erosion and idealistic thinking, 
- Lack of religion or values,

- Have experienced domestic violence or whose family has been dispersed,

- Addiction to drugs

What motivates organizations to use this tactic, how does suicide terrorism affect public opinion or how does society react to these events? In order for states to combat suicide terrorism, it is necessary to understand the dynamics of suicide bomber. Suicide terrorism, which is the most used attack method by terrorist organizations, progresses in direct proportion to the increase in the number of attacks worldwide, the proliferation of religious and separatist groups, and the increase of improvised explosive devices (IED). Suicide attacks as a part of asymmetric wars are important for the development of national and international security policies. Rebel groups using suicide bombers use different strategies, and these tactics cause traditional war strategies to change (Afflerbach \& Strachan, 2012: 438). The suicide attack carried out shows the terrorist's dependence on the group and ideology to which he/she belongs. Each suicide attack causes the organization to increase its legitimacy and provides inspiration for recruiting new members of the organization. The message the terrorist organization wants to convey is to explain to the enemy that its ideology is justified and that it has no other solution but violence and anger. Contrary to ordinary terrorist attacks, the suicide bomber's use of body as a weapon has a phenomenon of moral shame on the enemy. Although the main target of suicide attacks seems to be physical destruction, it is primarily to create a psychological war weapon used to influence large masses of people. Each suicide attack has a different motivation and ideology. As the reason for every suicide attack is not religious, it would be wrong to consider every suicide bomber as ethnic separatist. PKK / YPG and Tamil Tigers terrorist organizations carry out terrorist acts based on ethnic separatism, depending on the Marxist-Leninist ideology. Organizations such as ISIS, Al-Qaeda and the Taliban have adopted the Salafist jihadist ideology. The suicide attacks carried out for the Kashmir problem that has been going on for 72 years are attacks aimed at becoming a regional power beyond religious and national sensitivities. There is no difference between Osama Bin Laden or Abu Bakr Al-Baghdadi being accepted as a caliph by the members of the organization with jihadist ideology (AlQaeda, ISIS) and Abdullah Öcalan or Velupillai Prabhakaran as god by the members of the organization (PKK/YPG, Tamil Tiger) (Pedahzur, 2006: 25). Social, cultural, religious and financial incentives are provided to suicide attackers to attack by the organization. Especially while Islamic terrorist organizations make 
religious promises such as jihad, martyrdom and paradise, many terrorist organizations provide financial support to the families of the attackers. For financial support, which is one of the most used methods by terrorist organizations, terrorist organization leaders conduct cost-benefit analysis. Financial support has a enormous important place in order to ensure the functionality and continuity of the organization (Chandran, 2003: 29).

The most important motivation of suicide terrorism is the perception of humiliation and injustice towards a particular group or country. Attacks on the Palestinian people affect those who want to become Egyptian, Saudi Arabian and Iraqi suicide bombers. In the interviews of Nichole Argo with the unsuccessful suicide bombers in Israeli prisons, many of them reported that their relatives and friends had to carry them in the arms of the dead body and that the pictures of the murdered children affected them deeply. Lack of religious knowledge or a different or misinterpretation of religion may cause individuals to become enthusiastic about suicide terror. The religion, ideology or political culture of the suicide attackers is extremely important. Suicide terrorism inspires new generations. Children who grow up in such environments are raised to make the ultimate sacrifice to leaders of organizations such as Villupilai Prabhakaran or Abdullah Öcalan to serve the cause against the enemy. Being a suicide bomber is an altruistic behavior for terrorist organization militants. The phenomenon of honor, martyrdom and heroism for the perpetrator of the attack offers the opportunity to be remembered by affecting the wider group. According to Victor, Palestinian boys and girls under the age of six stated that they wanted to be a martyr when they grew up, but often did not even know the meaning of martyrdom. When they reach the age of twelve, they reiterate their determination that they want to be a martyr and they are appreciated for this (Pedahzur, 2006: 37). Suicide attacks are less costly than other types of terrorist attacks, they are more strategically useful because they are more lethal. Between 2000 and 2002, 44\% of terrorist attacks in Palestine were carried out by suicide attacks. Robert Pape argues that suicide terrorism is a strategy implemented by the people of the region under the control of democratic governments in order to expel the occupying states from their lands. According to Robert Pape, the presence of a foreign state in the territory of the country stated that it has an effect on organizational motivation with its reflection on domestic political dynamics (Pape, 2005: 61). 


\section{CONCLUSION}

The difference of suicide terrorism from other terrorist acts is that the success condition of the attack depends on the death of the attacker. It has been observed that suicide attackers do not have a profile that can be generalized according to countries, terrorist organizations or ethnicities and the factors that motivate suicide bombers can be versatile. In addition to religious expectations, it has been observed that many other factors with ethnic, economic, psychological and sociological dimensions can be motivating and terrorist organizations play an important role in the process of recruiting suicide bombers. The literature on suicide terrorism contains different findings about the factors that motivate individuals to be suicide attackers. Foreign occupation, religion, nationalism, feeling of hatred and revenge, economic factors, despair, injustice, humiliation, martyrdom and willingness to be remembered as a hero. Motivating factors change to personal, cultural and social characteristics and most importantly, according to the purpose, target and ideology of terrorist organizations.

The demographic characteristics of suicide bombers changes depending on the time, countries and terrorist organization. In this framework, it has been observed that the average age of suicide bombers varies between 20-25, most of them are not uneducated, receive good education, the number of female suicide bombers has increased over the years, and external occupation is an important factor.

Profiling of terrorists would be an appropriate method to prevent future attacks to combat suicide terrorism. In this context, interdisciplinary approaches should be adopted. 


\section{REFERENCES}

Abadie, A. (2004). Poverty, Political Freedom, and the Roots of Terrorism. John F. Kennedy School of Government, 96(2), 50-56.

Afflerbach, H., \& Strachan, H. (2012). How Fighting Ends: A History Of Surrender. Oxford: Oxford University Press on Demand.

Berge, W. V. D. (2014). History's Most Consequential Terrorist Attack. Terrorism and Political Violence Retrieved from https://leidensecurityandglo balaffairs.nl/articles/historys-most-consequential-terrorist-attack

Bloom, M. (2005). Dying to Kill: The Allure of Suicide Terror. New York: Columbia University Press.

Bryant, C. D. (2003). Handbook of Death and Dying. London: Sage.

Burgess, M. (2003). A Brief History of Terrorism. Center for Defense Information. Retrieved from https://www.pogo.org/investigation/2015/02/brief-history-ofterrorism/

Canter, D. V. (2010). The Faces of Terrorism: Multidisciplinary Perspectives. United Kingdom John Wiley \& Sons.

Chandran, D. S. (2003). Suicide Terrorism in South Asia: From Promised Land to Presumed Land. Institute of Peace and Conflict Studies. Retrieved from http://www.ipcs.org/focusthemsel.php?articleNo=1085

Combs, C. C. (2002). Terrorism in the 21 st Century. Boston: Routledge.

Corbin, C. M. (2017). Terrorists Are Always Muslim But Never White: At the Intersection of Critical Race Theory and Propaganda Fordham Law Review, $86(2), 455-485$.

Demircan, D., \& Aksüt, F. (2019). 48 Terrorists Surrendered to Turkish Forces

This Year. Anadolu Agency. Retrieved from https://www.aa.com.tr/en/turkey/4pkk-terrorists-surrender-to-turkish-forces/1651481

Gerwehr, S., \& Daly, S. A. (2006). Al-Qaida: Terrorist Selection and Recruitment. The RAND Corporation.

Graitl, L. (2017). Terror as Sacrificial Ritual? A Discussion of (Neo-)Durkheimian Approaches to Suicide Bombing. Cambridge University Press, 116-131.

Haberfeld, M., \& Hassell, A. (2009). A New Understanding of Terrorism: Case Studies, Trajectories and Lessons Learned. New York: Springer. 
Hafez, M. M. (2006). Suicide Terrorism in Iraq: A Preliminary Assessment of the Quantitative Data and Documentary Evidence. Studies in Conflict \& Terrorism, 29(6), 591-619.

Jacques, K., \& Taylor, P. J. (2008). Male and Female Suicide Bombers: Different Sexes, Different Reasons? . Routledge, 31(4), 304-326.

Kaplan, J. (2016). Waves of Political Terrorism. In Oxford Research Encyclopedia of Politics. New York.

Krueger, A. B. (2007). What Makes a Terrorist. New Jersey: Princeton University Press.

Kushner, H. W. (2003). Encyclopedia of Terrorism. United States of America: Sage Publications, International Educational and Professional Publisher.

Lankford, A. (2014). The Myth of Martyrdom: What Really Drives Suicide Bombers, Rampage Shooter, And Other Self-destructive Killers. Cambridge University Press, 37(4), 351-362.

Lester, D., \& Gunn, J. F. (2014). Suicide in Men: How Men Differ from Women in Expressing Their Distress. Springfield: Charles C Thomas, Publisher, Limited.

Madsen, J. (2004). Suicide Terrorism: Rationalizing the Irrational. Strategic Insights, 3(8).

Marthoz, J.-P. (2017). Terrorism and The Media: A Handbook for Journalists. France: United Nations Educational, Scientific and Cultural Organization

Merari, A. (2010). Driven to Death: Psychological and Social Aspects of Suicide Terrorism. Oxford: Oxford University Press.

Merari, A., Webber, D., Klein, K., Kruglanski, A., \& Brizi, A. (2017). Divergent Paths to Martyrdom and Significance Among Suicide Attackers. Terrorism and Political Violence, 29(5), 852-874.

Moghadam, A. (2006). Suicide Terrorism, Occupation, and the Globalization of Martyrdom: A Critique of Dying to Win. Studies in Conflict \& Terrorism, 29(8), 707-729.

Obaid-Chinoy, S. (2009). Children of Taliban From the PBS Documentary. Retrieved from https://www.pbs.org/video/frontlineworld-children-of-thetaliban/

Pape, R. A. (2005). Dying to Win: The Strategic Logic of Suicide Terrorism. New York: Random House. 
Parker, T., \& Sitter, N. (2016). The Four Horsemen of Terrorism: It's Not waves, It's Strains. Terrorism and Political Violence, 28(2), 197-216.

Pedahzur, A. (2006). Root Causes of Suicide Terrorism: The Globalization of Martyrdom. London: Routledge.

Post, J. M. (1990). Terrorist Psycho-Logic: Terrorist Behavior As a Product of Psychological Forces. Cambridge University Press, 25-40.

Rae, J. A. (2012). Will It Ever Be Possible To Profile The Terrorist. Journal of Terrorism Research, 3(2). Retrieved from https://cvir.st-andrews.ac.uk/ articles/10.15664/jtr.380/

Reuter, C. (2004). My Life is a Weapon: A Modern History of Suicide Bombing. United States of America: Princeton University Press.

Riaz, H. (2011). Suicide Bombings. New York: Routledge.

Schweitzer, Y. (2000). Suicide Terrorism: Development and Characteristics. International Institute for Counter-Terrorism: Online Article Series. Retrieved from https://www.ict.org.il/Article.aspx?ID=779\#gsc.tab=0

Shay, S. (2017). The Shahids: Islam and Suicide Attacks. New Jersey: Transaction Publishers.

Smith, M., \& Zeigler, S. M. (2017). Terrorism Before and After 9/11-A More Dangerous World? RAND Corporation Research and Politics, 4(4), 1-8.

Stack, S. (2004). Emile Durkheim and Altruistic Suicide. Archives of Suicide Research, 8(1), 9-22.

Stern, J. (2003). Why Religious Militants Kill: Terror in the Name of God. New York: Harper Collins Publishers.

Victor, B. (2003). Army of Roses: Inside The World of Palestinian Women Suicide Bombers. Emmaus, PA: Rodale Books.

Volkan, V. (2005). Suicide Bombers. The University of Virginia.

Volkan, V. (2010). İntihar Bombacılar1. Akademik Orta Doğu, 4(2), 1-8.

Volkan, V. (2013). Large Group Psychology in Its Own Right: Large-Group Identity and Peace-making. International Journal of Applied Psychoanalytic Studies, 10(3), 210-246.

Ward, V. (2018). What Do We Know About Suicide Bombing?: Review and Analysis. Politics and the life sciences, 37(1), 88-112. 